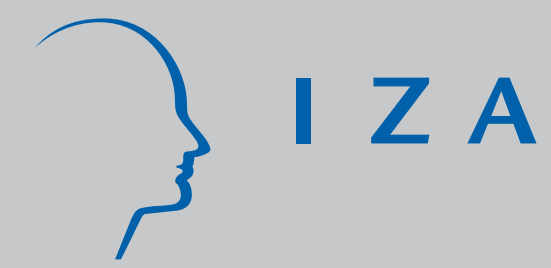

IZA DP No. 8647

The Effect of Female Leadership on Establishment and Employee Outcomes: Evidence from Linked Employer-Employee Data

Stefano Gagliarducci

M. Daniele Paserman

November 2014 


\title{
The Effect of Female Leadership on Establishment and Employee Outcomes: Evidence from Linked Employer-Employee Data
}

\author{
Stefano Gagliarducci \\ University of Rome Tor Vergata and IZA \\ M. Daniele Paserman \\ Boston University, NBER, CEPR and IZA
}

Discussion Paper No. 8647

November 2014

\author{
IZA \\ P.O. Box 7240 \\ 53072 Bonn \\ Germany \\ Phone: +49-228-3894-0 \\ Fax: +49-228-3894-180 \\ E-mail: iza@iza.org
}

\begin{abstract}
Any opinions expressed here are those of the author(s) and not those of IZA. Research published in this series may include views on policy, but the institute itself takes no institutional policy positions. The IZA research network is committed to the IZA Guiding Principles of Research Integrity.

The Institute for the Study of Labor (IZA) in Bonn is a local and virtual international research center and a place of communication between science, politics and business. IZA is an independent nonprofit organization supported by Deutsche Post Foundation. The center is associated with the University of Bonn and offers a stimulating research environment through its international network, workshops and conferences, data service, project support, research visits and doctoral program. IZA engages in (i) original and internationally competitive research in all fields of labor economics, (ii) development of policy concepts, and (iii) dissemination of research results and concepts to the interested public.
\end{abstract}

IZA Discussion Papers often represent preliminary work and are circulated to encourage discussion. Citation of such a paper should account for its provisional character. A revised version may be available directly from the author. 


\section{ABSTRACT \\ The Effect of Female Leadership on Establishment and Employee Outcomes: Evidence from Linked Employer-Employee Data}

In this paper we use a large linked employer-employee data set on German establishments between 1993 and 2012 to investigate how the gender composition of the top layer of management affects a variety of establishment and worker outcomes. We use two different measures to identify the gender composition of the top layer based on direct survey data: the fraction of women among top managers, and the fraction of women among working proprietors. We document the following facts: a) There is a strong negative association between the fraction of women in the top layer of management and several establishment outcomes, among them business volume, investment, total wage bill per worker, total employment, and turnover; b) Establishments with a high fraction of women in the top layer of management are more likely to implement female-friendly policies, such as providing childcare facilities or promoting and mentoring female junior staff; c) The fraction of women in the top layer of management is also negatively associated with employment and wages, both male and female, full-time and part-time. However, all of these associations vanish when we include establishment fixed effects and establishment-specific time trends. This reveals a substantial sorting of female managers across establishments: small and less productive establishments that invest less, pay their employees lower wages, but are more femalefriendly are more likely to be led by women.

JEL Classification: D22, J16, J70, M50

Keywords: $\quad$ gender, firm performance, employer-employee data

Corresponding author:

M. Daniele Paserman

Department of Economics

Boston University

270 Bay State Road

Boston, MA, 02215

USA

E-mail: paserman@bu.edu

\footnotetext{
*We would like to thank two anonymous referees, seminar participants at the AFA 2014 Meeting, the IZA Workshop on Gender Convergence 2014 and Mills-Bocconi, for their insightful comments.
} 


\section{Introduction}

Despite large increases in female labor force participation rates over the past five decades, women are still substantially underrepresented in top leadership positions in the corporate world. Nevertheless, the numbers have been steadily increasing: the share of women among top corporate officers of Fortune 500 companies has risen from $8.7 \%$ in 1995, to $15.7 \%$ in 2008. ${ }^{1}$ It is reasonable to expect that this trend will continue in the foreseeable future, as the gender gap in educational attainment (favoring women) continues to grow (Goldin et al., 2006), and the share of women attending and graduating from business schools now approaches $50 \% .^{2}$

It is natural to ask what effect the increasing representation of women at the top can have on firm outcomes. A growing literature, following Bertrand and Schoar (2003) has shown that individual manager characteristics matter for firm performance. While most of the literature has focused on management style or specific attitudes of top managers (such as risk aversion), only a limited number of studies in the economics literature have looked explicitly at the effect of gender on firm's outcomes. Women advocacy groups often make the claim that a more diverse leadership can achieve better performance for the firm by leveraging to the full extent the available talent pool. ${ }^{3}$ One important dimension in which the gender of the leadership may affect outcomes is in wage policies. If the gender gap in wages is at least in part due to discriminatory behavior by (mostly male) executives, one would expect that a higher representation of women in the top echelons of management would

\footnotetext{
${ }^{1}$ Source: http://www.catalyst.org/knowledge/women-corporate-officers-fortune-500. The Census of Corporate Officers and Top Earners of Fortune 500 Companies has been conducted annually since 1996 by Catalyst, a non-profit organization with a mission to expand the opportunities of women and business.

${ }^{2}$ NCES, Digest of Education Statistics, 2012. See also Bertrand et al. (2010). Recent figures, however, show that this progress may have stalled after years of accelerating ("An Elusive Jackpot: Riches Come to Women as C.E.O.s, but Few Get There", The New York Times, June 7, 2014).

${ }^{3}$ For example, in her best-selling book Lean In, Sheryl Sandberg (2013) writes that "...The laws of economics and many studies of diversity tell us that if we tapped the entire pool of human resources and talent, our collective performance would improve."
} 
lead to a narrowing of the gender pay gap, and more opportunities for the advancement of women inside the firm hierarchy. Alternatively, female executives, being more attuned to the needs of female employees, may be more likely to promote female friendly policies, such as provision of child care or specific mentoring programs. ${ }^{4}$

The goal of this paper is to explicitly investigate how the gender composition of the top layer of management affects firm and employee outcomes. To this purpose, we use a large linked employer-employee data set on German establishments between 1993 and 2012. The longitudinal nature of the data set allows us to control for the most obvious source of bias deriving from the nonrandom allocation of women to top leadership positions, by estimating models with a rich dynamic structure of firm unobservables. Moreover, the linked employer-employee nature of the data means that we can look at both establishment outcomes, such as business volume, investments, and specific policies targeted at women; and detailed employee-level outcomes, such as employment and wages by full-time/parttime status.

The main findings can be summarized as follows: a) There is a strong negative association between the fraction of women in the top layer of management and several establishment outcomes, among them business volume, investment, the total wage bill per worker, total employment, and turnover; b) Establishments with a high fraction of women in the top layer of management are more likely to implement female-friendly policies, such as providing childcare facilities or promoting and mentoring female junior staff; c) The fraction of women in the top layer of management is also negatively associated with employment and wages, both male and female, full-time and part-time. However, all of these associations vanish

\footnotetext{
${ }^{4}$ It is not obvious, however, that the gender of the leadership should have any effect on firm outcomes: the neoclassical view of the firm assumes that "top managers are homogeneous and selfless inputs into the production process" (Bertrand and Schoar, 2003, p. 1173), and therefore, even if executives differ in their preferences or attitudes because of their gender, this will have no effect on firm policies or outcomes. By contrast, standard agency models acknowledge that the objectives of managers and shareholders may not necessarily be aligned, and therefore personal manager characteristics may have an effect on their decisions.
} 
when we include establishment fixed effects and specific time trends, suggesting no causal link between women's representation in top management and establishment outcomes. Instead, there appears to be substantial sorting of female managers across establishments: small and less productive establishments that invest less, pay their employees lower wages, but are more female-friendly are more likely to be led by women.

The results are mostly inconsistent with simple theories of labor market discrimination, which would predict that, if women have less discriminatory tastes toward other women, then a higher fraction of women in leadership positions would lead to improved relative employment and wage outcomes, as well as to higher productivity. We also find no evidence that women in leadership positions implement policies that would be more friendly to female employees. These figures are broadly in line with much of the previous literature, which has tended to find mostly zero or negative effects of female leadership on firm performance (Bertrand et al., 2014).

The rest of the paper is organized as follows. In Section 2, we review the related literature. In Section 3, we describe the data. In Section 4, we describe the econometric framework and discuss the conditions under which this design identifies a parameter of interest. In Section 5 we present the main results and discuss possible interpretations to our findings. We conclude with Section 6.

\section{Literature Review}

There is by now a growing body of literature in economics that looks at the relationship between the fraction of women in the top echelons of firms' hierarchies and a variety of firm outcomes. The studies differ in the types of firms under analysis, in the definition of female leadership, and in the main outcomes of interest. The studies can be broadly grouped in two categories: those that focus on corporate outcomes such as profits, investment, stock returns, 
and Tobin's Q, and those that focus more on employee outcomes. Within the first category, we can further distinguish between those that analyze specifically the effects of women in top executive positions, and those that instead focus more on issues of governance, and the role of women among the board of directors. Within this latter category, the studies that exploit the imposition of a gender quota in Norwegian listed firms deserve a special mention. A summary of some of the most prominent studies in this literature is presented in Table 1. The Table highlights how these differ in terms of the characteristics of the sample, the definition of female leadership, the outcomes of interest, and the methodology used. In what follows we discuss these studies more at length.

One of the first studies that investigates the effects of female leadership on firm performance is Wolfers (2006). He uses a combination of OLS and matching methods and finds no evidence of systematic differences in excess returns to holding S\&P stock of female-headed companies. Smith et al. (2006), using both OLS and IV methods (where the fraction of women in top management is instrumented by the education of male CEO's wives), find that the proportion of women in top management jobs tend to be positively associated with firm performance in a panel of large Danish firms, but the association becomes largely insignificant once one controls for firm fixed effects. Amore et al. (2013) find that only the joint presence of women in CEO and governance positions significantly improves firm performance in a sample of family-controlled firms in Italy. ${ }^{5}$ Using a subset of the data that we use in this paper, Laible (2013) finds a slight negative correlation between the proportion of women in top management and establishment performance. In a slightly different vein, Parrotta and Smith (2013) document the existence of a negative association between female CEO and the variability of firm outcomes, in line with the experimental evidence that women typically exhibit higher risk aversion than men (Croson and Gneezy, 2009).

\footnotetext{
${ }^{5}$ Gagliarducci and Paserman (2012) also find important interaction effects between the gender of the leader and that of the immediate subordinates in the political arena.
} 
The second set of studies focuses more on firm governance, and in particular on the role women in the board of directors. Adams and Ferreira (2009) find that, in a sample of US firms, female directors have better attendance and do more monitoring but gender diversity has a negative effect on firm performance. These results are robust to instrumenting the fraction of women directors with the fraction of male directors that are connected (through other boards) with female directors. Adams and Funk (2012) document that female and male board directors differ in their core values and risk attitudes, but in ways that diverge from gender differences in the general population. For example, female directors are more universally concerned and less power oriented, but they are also more risk-loving than their male counterparts.

More recently, various authors have examined the introduction in Norway of gender quotas on executive boards. The Norwegian reform, which was enacted in December 2003, required all public limited liability companies to have at least $40 \%$ of board directors from each gender within two years of the passage of the law. Ahern and Dittmar (2012) found that affected firms (i.e., firms that were induced by the law to substantially increase the representation of women on their board) experienced a significant drop in stock prices at the time of the announcement of the law, and that firm performance, as measured by Tobin's Q, was also negatively affected. They also found evidence that newly appointed female board members were on average less experienced. Matsa and Miller (2013) also found a decrease in profits and assets, as well as an increase in employment and labor costs in "treated" firms. However, it should be noted that a substantial fraction of limited-liability companies switched their legal status after the enactment of the law, making them no longer subject to the gender quota, and thus introducing potential survivor bias in the analysis of the reform.

On the whole, the literature on firm performance finds little evidence of a positive effect of female leadership on firm outcomes, with some studies in fact finding evidence of negative effects. Even when the effects are positive, the results are sometimes qualified, and not 
always robust to econometric methods that account more credibly for potential endogeneity of the female leadership variable.

A more limited number of studies have looked instead at the effect of the gender composition of top management on the level and distribution of employee wages. Flabbi et al. (2013) use a matched employer-employee data set on Italian manufacturing firms and a fixed effects identification strategy to show that the interaction between female leadership and female workers at the firm has a positive significant impact on sales, value added and TFP per worker. Moreover, they document that female leadership leads to wage increases for women at the top of the wage distribution, and wage decreases for women at the bottom. They interpret their results in terms of a simple model of statistical discrimination, in which an inefficient gender allocation across the firm is only corrected when female leadership takes over. Cardoso and Winter-Ebmer (2007) use Portuguese firm-level data and a fixed effects strategy, and find that, while a higher share of females in a firm corresponds to lower wages for both female and male workers, female workers benefit from higher wages in female-led firms than in male-led firms. Tate and Yang (2014) also find some indirect evidence on the effect of female leadership on the gender gap: following a plant closure, female wages drop by substantially less if they move to a new firm with a higher fraction of female managers. However, in the context of the Norwegian reform, Bertrand et al. (2014) find essentially no effect of female board members on the fraction of women at various points of the wage distribution (with the exception of the top 5 earners), and no effect on the gender gap. Finally, Matsa and Miller (2014) use a sample of privately owned US firms to look at employment outcomes. They find that female ownership is associated with smaller workforce reductions during the Great Recession.

With respect to this literature, our contribution is threefold. First, our sample is representative of the universe of establishments in Germany, and therefore we are not limited to the analysis of establishments of a specific sector, size, or legal form; moreover, the fact 
that we observe also a large number of small and medium-sized establishments implies that the fraction of women in top management is relatively high. Second, the linked employeremployee nature of our data means that we are able to observe both establishment outcomes (such as sales, investments), and employee outcomes (such as employment and wages). One of the distinct features of our study is that we also have unique information on the implementation of female-friendly personnel policies. Having the complete roster of the firms' employees allows us to look specifically at the outcomes of employees who are not part of top management. Third, the long nature of our panel (some firms are observed continuously for almost 20 years) allows us to specify a rich dynamic structure for the error term in our econometric specification. In particular, controlling for establishment-specific time trends allows us to control for any time-varying unobserved patterns that may play a key role in determining establishment and employee outcomes, and are also correlated with the fraction of women in top management. Much of the existing literature used instead a simple fixed effects strategy; an IV strategy with instruments whose orthogonality with respect to time-varying unobservables at the firm level may not always be justified; or exploited the natural experiment induced by the imposition of gender quotas in Norway, effectively obtaining identification from the variation in the share of women in the board of directors prior to the reform. We therefore view our approach as complementary to the existing literature.

\section{Data}

The IAB Establishment Panel is an annual representative survey of German establishments that has been conducted by the IAB (Institute for Employment Research - Institut für Arbeitsmarkt und Berufsforschung) since 1993 (and since 1996 in East Germany). It gathers yearly information for about 4,000-16,000 establishments on employment, business policy,

investments, personnel structure, wages, and general company information. Each wave has 
a supplementary questionnaire with additional information on specific topics, ranging from IT equipments to environmental standards. The last available wave is the 2012 one. ${ }^{6}$

Matched with the employee social security history from 1993 to 2010, the Establishment Panel forms the Linked Employer/Employee Data (LIAB). Individual data cover sociodemographic characteristics (gender, year of birth, nationality, education and professional qualifications), and employment-related characteristics (start and end date of employment, type of employment, gross earnings, profession, occupational status, reason for employment notification) of all employees (both full-time and part-time), trainees and apprentices of IAB establishments subject to social insurance payments, as well as marginal part-time employees. Some categories of workers, e.g., civil servants, the self-employed, working proprietors, and unpaid family workers are not subject to social insurance, and are therefore not included in the LIAB. ${ }^{7}$

For our analysis, we restrict attention to establishments in West Germany that have at least 10 employees in each survey year. This restriction ensures that we have a sample of relatively large and stable establishments. All estimates are based on both private and public sector establishments, except for those on business volume and investments per worker, which are based on private sector establishments only. ${ }^{8}$

In order to identify the fraction of women in top management, we rely on two different survey-based measures. The first measure comes from the supplementary questionnaire focusing on senior management conducted in the 2004, 2008, and 2012 waves of the IAB Establishment Panel. In these three waves, establishments were asked to report directly the number of managers in the top layer (including proprietors, their family members, directors,

\footnotetext{
${ }^{6}$ Data is collected at the establishment level, so it is possible that some establishments belong to the same firm. It is not possible, however, to link establishments by ownership.

${ }^{7}$ Working proprietors include all individual proprietors and partners actively engaged in the work of the establishment, excluding silent or inactive partners whose principal activity is outside of the establishment. See also the OECD Glossary of Statistical Terms.

${ }^{8}$ Public sector establishments are not Public Administration, but service providers like: waste collection, radio and telecommunications, health care, and entertainment.
} 
and branch managers), separately by gender. The second measure, which also comes from the IAB Establishment Panel, is the fraction of women among working proprietors, including their family members. This measure is available in 1993, and then every year from 1997 onwards. ${ }^{9}$

Table 2 describes some of the basic characteristics of our sample. The second and third columns show the number of establishments present in each wave, and those that remain in our main analysis sample after imposing the geographic and size restrictions. The number of establishments in the survey has significantly increased over time, as much as the corresponding number of establishments in the analysis sample. The remaining two columns show the evolution of the fraction of women in the top layers of management over time, according to the two different measures. The fraction of women in top management went from $13.9 \%$ in 2004 to $18.5 \%$ in 2012 . These numbers are only slightly higher than the fraction of women among working proprietors, which went from $8 \%$ in 1997 to $15.8 \%$ in 2012 . It is interesting to notice that both measures exhibit an increasing trend over time, which is evidence of a reduction in the gender glass ceiling. For the years in which both measures are available, the correlation between the two is 0.97 .

Table 3 reports the characteristics of the establishments in the analysis sample. Almost $37 \%$ of the establishments have less than 50 employees, $46 \%$ have between 50 and 500 employees, while the remaining 17\% have more than 500 employees. Most of the establishments are independent $(57 \%)$, while $28 \%$ are a branch and $15 \%$ are the head office of a group of establishments. At the same time, $55 \%$ of the establishments are a limited liability com-

\footnotetext{
${ }^{9}$ The second measure is not available for all establishments surveyed in a given year, because some establishments do not have any working proprietors. This may raise concerns of potential selection bias, as establishments with and without working proprietors may differ systematically. However, it turns out that the two samples are in fact quite similar along several dimensions: for example, among establishments with more than 10 employees in the whole sample, 39.8\% have 10-49 employees, $47.8 \%$ have between 50 and 499 employees, and $12.3 \%$ have more than 500 employees; the corresponding numbers for establishments with any working proprietors are $42.4 \%, 44.6 \%$ and $12.8 \%$. The distribution by region or by economics sector are also quite similar.
} 
pany, $6 \%$ are a partnership, $7 \%$ are individually-owned, and $17 \%$ are public corporations. The largest fraction of establishments is in the manufacturing sector (28\%), followed by the retail $(12 \%)$ and the public sector $(12 \%)$. Interestingly, $70 \%$ of the establishments are observed at least two times and $54 \%$ at least three times, thus providing a sufficiently large longitudinal variation for the panel identification (see the next section).

Table 4 reports summary statistics for our key dependent variables of interest. The top panel refers to firm-level outcomes obtained from the establishment survey, while the bottom panel refers to employee-level outcomes calculated from the linked employer-employee data. The average establishment has a total of 107 employees, with average labor costs of 2,083 euros per month, produces 124,661 euros of business volume in the year, and makes investments per worker in the order of 208 euros per year. ${ }^{10}$ The hiring rate and the termination rate have a similar magnitude (5\%), with a resulting turnover rate of about $10 \%$.

The next set of variables reflects establishment-level policies that are designed to facilitate the integration of women in the workforce. First, we report the fraction of employees who are allowed to use a flexible working-time account, a variable that is available in the establishment survey in selected years between 1999 and 2012. The average establishment had about $50 \%$ of its employees with access to flexible working hours. Next, we construct an index of female-friendly policies, using the supplement on equal opportunity available in the establishment survey in 2002, 2004, 2008 and 2012. Establishments were presented with a list of "possibilities to enhance equal opportunity," and were asked to indicate which of these measures existed within the company. Because the exact number of measures varies across years, we construct a simple index of female-friendly policies as the simple average across all measures in a given year. The average value of this index is 0.14 , with $46 \%$ of establishments implementing at least one female friendly policy. We also report on three spe-

\footnotetext{
${ }^{10}$ All monetary values are expressed in 2005 euros. Business volume is either sales or assets (if a financial institution). Business volume and investments are not available in 2012.
} 
cific measures on which we have consistent information in every year: $9 \%$ of establishments provide childcare facilities, $26 \%$ have policies to support parental leave, and $10 \%$ actively engage in promotion and mentoring of junior female staff. ${ }^{11}$

Most of the individual level variables, which refer to workers in bottom $95 \%$ of the within-establishment wage distribution, are in line with what expected: on average there are more men than women, while women are overrepresented among part-time workers, both in absolute and relative terms. Wages present similar dynamics, with men being paid more than women: the gender gap in both full-time and part-time wages stands at about $17 \log$ points. 12

\section{Methodology}

Let $Y_{j t}$ be a variable representing both establishment $j$ outcomes (such as business volume, investments, wage bill, hiring, and termination), and detailed employee-level outcomes (such as wages and employment, by gender and full-time/part-time status) at time $t$. We estimate the following model by ordinary least squares (OLS):

$$
Y_{j t}=\alpha+\beta F r W o m T o p_{j t}+\gamma^{\prime} X_{j t}+\lambda_{j}+t_{i m e}+\epsilon_{j t}
$$

where $\mathrm{FrWomTop}$ jt is the fraction of women in the top layer of management of firm $j$ at time $t$ (based on one of the two definitions described previously); $X_{j t}$ is a vector of establishment characteristics that includes year, region, sector, firm size, type of establishment and legal form dummies, plus the average demographic characteristics (age, education, tenure at the firm, and foreign nationality status) of the management level, identified as the $5 \%$ highest

\footnotetext{
${ }^{11}$ Other female friendly policies that are not asked consistently in every survey wave include: support for employees with relatives requiring care, consideration of needs of employees with care responsibilities, member of network of family friendly companies.

${ }^{12}$ Employee data only refer to workers entitled to social security. These do not include working proprietors, unpaid family workers, self-employed, civil servants, and marginal part-time workers.
} 
earning workers, and dummies for whether any of the establishment or demographic characteristics are missing; $\lambda_{j}$ is an establishment fixed-effect that accounts for any time-invariant unobserved characteristics, and time $_{j}$ is an establishment-specific linear time trend that accommodates for smooth unobserved changes at establishment level. By construction, the identifying sample in the model with establishment fixed effects consists of establishments observed at least twice in time, while the identifying sample in the model that also includes firm-specific time trends consists of establishments observed for at least three times. To account for potential serial correlation in the error term, we always cluster standard errors at the establishment level.

The main advantage of the long panel and the empirical methodology is that it achieves identification only from the within-establishment variation in the fraction of women in top management, or the deviation of this variable from its long-term trend. The inclusion of establishment fixed effects allows us to remove the most obvious source of confounding variation, namely that establishments with a high fraction of women in top management may be unobservably different in terms of productivity, employment, wages, or any of the other outcome variables. Moreover, comparison between pooled OLS and fixed-effect estimates will provide valuable insights on the nature of sorting of female leadership across different types of establishments. The extensive list of control variables allows us to control for any important time-varying establishment characteristics that may be correlated with both outcomes and the fraction of women in top management: for example, if female managers are on average younger, and establishments with younger managers experience different outcomes, this will be captured by the inclusion of the average demographic characteristics of the top management. ${ }^{13}$ Finally, the inclusion of establishment-specific time trends allows us to control for additional within-establishment unobservables that change linearly with time.

\footnotetext{
${ }^{13}$ While in most specifications we include the full set of control variables, in some cases we omit variables that are obviously related to the dependent variable: for example, when the dependent variable is employment, we do not control for establishment size.
} 
For example, a smooth change in "firm culture" that leads to modernization and increased efficiency of production processes, and at the same time to more widespread acceptance of women in leadership positions, would be accounted for by our methodology. The limitation of the methodology is that it cannot accommodate for sharp unobserved changes in establishments' strategies and outcomes, such as those deriving from a change in the composition of shareholders, or a sudden financial downturn that leads to a change in the gender composition of the top layer of management.

\section{Results}

Establishment Outcomes. Tables 5 and 6 presents the results for the effect of the fraction of women in the top layer of management on establishment outcomes. For each dependent variable we report the coefficients from three separate regressions: pooled OLS, controlling for establishment fixed effects, and controlling for establishment fixed effects and establishment-specific trends. We also report two different sets of coefficients, one for each of the two measures female leadership: the fraction of women in the top layer of management, as elicited in the supplementary module on senior management in 2004, 2008 and 2012 (in short, the fraction of women in the top layer); and the fraction of women among working proprietors. ${ }^{14}$ In all estimates we control for year, region, sector, establishment size and legal form dummies, plus the average demographic characteristics (age, education, tenure at the establishment, and foreign nationality status) of the management level, identified as the $5 \%$ highest earning workers, and dummies for whether any of the establishment or demographic

\footnotetext{
${ }^{14}$ For business volume and investment, we cannot compute estimates based on establishment-specific time trends, when the measure of female leadership is the fraction of women in the top layer of management. This measure is available only in three years, 2004, 2008 and 2012. Questions about business volume and investment are asked in the establishment survey (which goes up to 2012), but they refer to the previous calendar year and therefore are unavailable for 2012.
} 
characteristics are missing. ${ }^{15}$

The top panel of Table 5 focuses on establishments' balance sheet outcomes, as reported in the establishment survey: business volume per worker, investment per worker, and the wage bill per worker. The bottom panel, instead, looks at employment outcomes, as reported in the establishment survey: log of total employment; the hiring rate, defined as the number of new hires in year $t$ divided by the number of employees in year $t-1$; and the termination rate, defined analogously. ${ }^{16}$

The OLS regressions show that, no matter which definition we use, the share of women in top management is strongly negatively correlated with each of the establishment balance sheet outcomes and with total employment, and positively correlated with the mobility measures. The point estimates based on the two different measures of female leadership are quite similar to one another, even though the estimates based on the second measure (the fraction of women among working proprietors) are generally more precise, because of the longer panel available to us. Looking at the magnitude of the coefficients, we see that going from an entirely male to an entirely female top layer of management is associated with roughly a 0.2-0.3 standard deviation change in the dependent variable. This evidence seems to validate the results of previous studies showing a negative relationship between female leadership and firm performance (Adams and Ferreira, 2009; Ahern and Dittmar, 2012).

However, inclusion of establishment fixed effects makes all of these negative correlations completely vanish. Not only are most of the estimates no longer statistically significant, they are also quite small in magnitude. For example, going from an entirely male to an entirely female top layer of management is not associated with any variation in business volume per worker, employment, hiring or termination rates, and only a 1.2 percentage point decline in

\footnotetext{
${ }^{15}$ We do not report the coefficients for these additional control variables. They all turned to have the expected sign and magnitude, and are available upon request.

${ }^{16}$ The survey based measures of wages include, by construction, the top managers themselves and their wages. The analysis based on individual-level data (Table 7) will enable us to focus only on the workers not in management positions.
} 
the wage bill per worker. These small effects are precisely estimated, especially in the specification that uses the fraction of women among working proprietors as the measure of female leadership. We can rule out effects as small as 3 log points in business volume, employment, and the size of the wage bill. The results are essentially unchanged in the specifications with firm-specific time trends. This suggests that most of the spurious correlation between establishment outcomes and the fraction of women in top management is already soaked up by the establishment fixed effects, and any additional establishment unobservables that change linearly over time are uncorrelated with the fraction of women in top management.

The contrast between the OLS and the fixed effects specifications shows that there is substantial sorting of female managers across establishments: smaller and less productive establishments that invest less, and have higher turnover are more likely to be led by women. Note that the OLS specifications also control for industry dummies, so the results are not due just to women sorting into sectors with lower productivity, wages, and employment stability; rather, even within sectors, women in top management are more likely to be found in establishments with these characteristics.

In Table 6 we report on the correlation between the fraction of women in top management and the presence of female-friendly policies. The first panel looks at the fraction of workers on flexible time accounts, and on the aggregate female-friendly policy index described in Section 3. Interestingly, the OLS specification points to a negative relationship between female leadership and the fraction of workers on flexible time (statistically significant when measuring female leadership as the fraction of women in top management). Inclusion of establishment fixed effects and establishment specific time trends make the relationship become insignificant, even though the point estimate remains negative, and of similar magnitude. We suspect that this negative association can be explained by the fact that flex time arrangements are much more common in large manufacturing establishments, which are substantially less likely to have women in top positions. Even though we control for 
establishment size and sector dummies in the regressions, this may not be enough to entirely remove the spurious correlation.

On the the other hand, there is a positive and statistically significant association between the female-friendly policy index and female leadership in the OLS specifications, and the coefficient maintains its magnitude when we control for establishment fixed effects and establishment specific time trends, even though the estimate loses in precision. The size of the coefficient is not negligible: going from zero to one hundred percent women in top management is associated with an increase in the index of 1.3-2.5 percentage points, a 9 to 17 percent increase relative to the baseline of 0.146 . The bottom panel of the Table shows the coefficients for some of the specific policies for which we have consistent information over multiple years. Female leadership is strongly associated with offering workplace child care facilities and (to a lesser extent) with promotion and mentoring programs for junior female staff. On the other hand, there doesn't seem to be much of a relationship between female leadership and help for employees on parental leave. Summing up, the evidence is only mildly supportive of the idea that women in top management are able to promote more female-friendly workplace policies, but the estimates are too imprecise to convincingly establish a causal link.

Detailed Employee Outcomes: Employment. One of the main advantages of the linked employer-employee data is that it allows us look in more detail at employee outcomes. Specifically, we can use the data to investigate whether the null effects on total employment found in the previous analysis may in fact mask important differences in the effects on male versus female employment, or part-time versus full-time employment. In addition, data on wages allows us to assess the extent to which labor market discrimination plays a role in explaining the gender gap in wages. We investigate these issues in Tables 7 and 8 .

Table 7 looks at the relationship between the fraction of women in top management and employment outcomes, separately for males and females, and for full-time (top panel) and 
part-time employment (bottom panel). As in the previous tables, we report for each dependent variable the estimates from pooled OLS, fixed effects, and firm-specific time trends specifications. ${ }^{17}$ As discussed previously, we want to focus only on the effect of top management on the outcomes of non-management employees, and therefore we restrict the analysis to workers in the bottom $95 \%$ of the wage distribution within firms. This should also ensure that we avoid any mechanical relationship between our key right-hand side variable and any of the dependent variables.

The OLS estimates show a strong negative correlation between the share of women in top management and both female and male full-time employment, with the latter coefficient being about 4-6 times as large. While these results confirm the pattern found in Table 5, the difference in coefficients shows that there is important heterogeneity in the relationship between the share of female in top management and firm size. Female leaders are especially unlikely to be found in firms with a large number of male full-time employees, but only slightly less likely to be in firms with a high number of female employees. As in the previous tables, the inclusion of establishment fixed effects makes the coefficients become small and insignificant. In the specification that uses the fraction of women among working proprietors, we can rule out effects as small as 3.5-3.8 log points.

We find a similar pattern for part-time employment (bottom panel). There is a strong negative OLS association between female leadership and male part-time employment. On the other hand, the OLS coefficient on female part-time employment is zero or even mildly positive. Inclusion of establishment fixed effects makes all the coefficients become smaller in magnitude and statistically insignificant.

Interestingly, the absence of any effect on employment and mobility variables (from Table

\footnotetext{
${ }^{17}$ The individual-level data only goes up to 2010. Therefore, we can only use two years of data (2004 and 2008) for the specification that uses the fraction of women in top management as the measure of female leadership. Because of this, we cannot estimate models with establishment-level time trends when using this measure.
} 
5) is in contrast with the recent findings of Matsa and Miller (2013 and 2014), who found that a higher fraction of women in top management led to higher employment and labor costs (in Norway), and smaller workforce downsizing during recessions (in the US). The difference in our results could be due to the fact that our sample includes all types of firms (not only large corporations, where agency problems may arise), and covers a period that spans the whole business cycle, and not just the Great Recession.

Detailed Employee Outcomes: Wages. A taste-based model of labor market discrimination would predict that, if female employers are less prejudiced against women, then a higher share of women in top management would reduce the gender pay gap. Theories of statistical discrimination would also predict an effect of female leadership on the gender gap, if, for example, female employers have better information about the productivity of female workers. It is therefore important to test whether we find any support for such theories in the data.

Table 8 looks at the effect of female leadership on the average wages of employees in the bottom $95 \%$ of the within-establishment wage distribution. To avoid confounding the effects because of heterogeneity in worker type, we report separately the effects for wages of full-time (top panel) and part-time workers (bottom panel). The first set of columns reports the results for female workers, and the second for male workers.

We do not observe a positive effect of female leadership on the relative remuneration of female employees. As a matter of fact, the regressions show that female leadership is associated with lower wages of both male and female employees, and for both full-time and part-time workers, the size of the coefficient being larger (in absolute value) for men. All the estimated effects, however, are markedly attenuated when we control for firm fixed effects and firm-specific time trends. Female leadership is associated with a decline of 1.5-2.7 log points in female full-time wages, and to a decline of 0.4-2.2 $\log$ points in male full-time wages. The coefficients on female wages are estimated somewhat more precisely, but there 
is no statistically significant effect on the gender gap (not reported). The negative effect of female leadership on part-time wages is somewhat smaller for women and somewhat larger for men, although the coefficients are never statistically significant, nor is there any statistically significant effect on the gender gap.

These results are similar to those of Bertrand et al., but not consistent with those of Cardoso and Winter-Ebmer (2007), Flabbi et al. (2013), and Tate and Yang (2014), who found some evidence of a positive association between the relative wage outcomes of women and the share of women in top management. One possible explanation for the discrepancy is that both Germany and Norway rank somewhat higher than Portugal, Italy, or the US in terms of economic opportunities for women (Economist Intelligence Unit, 2010), and therefore the trickle-down effect of more women in top positions on relative wages may be more muted.

Robustness. For all the above estimations we conducted a series of robustness exercises: first, in all the estimates on employee outcomes we also included demographics characteristics of the bottom $95 \%$ of employees (mean age and tenure, and percentage of college graduates and non-Germans); second, we included a firm-specific quadratic trend, instead of linear. The main results remain almost unchanged in these alternative specifications. ${ }^{18}$

As a further robustness exercise, in Tables 9 and 10 we provide separate estimates by establishment size (10-49, 50-499, 500+ employees) for a few selected outcomes. ${ }^{19}$ We only report the estimates using the fraction of women among working proprietors as the measure of female leadership, because with the other measure (available in only three years) we do not have sufficient observations to break down firms by establishment size. While it is true that in all previous estimates we were controlling for the size of the establishment, it may still be

\footnotetext{
${ }^{18}$ These results available upon request. Since the three models (OLS, fixed effects, firm-specific time trends) have different identifying samples, we also estimated an OLS model over the fixed effects sample, and a fixed effects model over the firm-specific time trends sample, with no significant differences on the estimated coefficients.

${ }^{19}$ Estimates on the other outcomes are available upon request.
} 
valuable to investigate whether the effect of the percentage of women among top management differs between large (e.g., a factory) and small (e.g., a retail store) establishments. Most of these additional figures are in line with our baseline results: regardless of size, establishments with more women among working proprietors have a higher female friendly policy index (Table 9) and lower full-time employment and wages (Table 10), even though all these effects disappear once controlling for establishment fixed effects and for specific time trends. More interestingly, we could not find any significant difference between establishments of a different size, except that the negative effect on wages seems to be stronger in large establishments than in small ones (but only for women). We conclude that the size of the establishment does not seem to interact with the presence of more women in the top management.

\section{Conclusion}

In this paper, we have documented the effect of female leadership on aggregate and employee outcomes in a large panel of German establishments. The evidence points to a large degree of sorting, with the share of women in top management higher in establishments that are smaller, less productive, invest less, are more female-friendly, have less stable patterns of employment, and pay their employees lower wages. However, when we address potential reverse causality by estimating models with establishment fixed effects and establishment-specific time trends, all of the relationships at the establishment level become small in magnitude and statistically insignificant. In fact, in most specifications we find a fairly precisely estimated null effect of female leadership.

The results are mostly inconsistent with simple theories of labor market discrimination, which would predict that, if women have less discriminatory tastes toward other women, then a higher fraction of women in leadership positions would lead to improved relative employment and wage outcomes, as well as to higher productivity. We also find no evidence 
that women in leadership positions implement policies that would be more friendly to female employees.

In conclusion, while it certainly may be desirable to promote a higher presence of women in leadership positions on the grounds of equality of opportunity, and possibly because of long-term considerations (e.g., women today may serve as role models for younger generations, and thus help to break the glass ceiling), the findings in this paper do not support the view that a higher concentration of women at the top of the organizational hierarchy leads to tangible effects on either firm outcomes or on relative female standing in the workplace. 


\section{References}

[1] Adams, R.B. and Ferreira, D., 2009. "Women in the Boardroom and their Impact on Governance and Performance." Journal of Financial Economics, 94, 291-309.

[2] Adams R.B. and Funk P., 2012. "Beyond the Glass Ceiling: Does Gender Matter?." Management Science, 58, 219-235.

[3] Ahern K. R. and Dittmar A. K., 2012. "The Changing of the Boards: The Impact on Firm Valuation of Mandated Female Board Representation." The Quarterly Journal of Economics, 127, 137-197.

[4] Amore M. D., Garofalo O. and Minichilli A., 2013. "Gender Interactions Within the Family Firm." Management Science, forthcoming.

[5] Bertrand M., Black S., Jensen S. and Lleras-Muney A., 2014. "Breaking the Glass Ceiling? The Effect of Board Quotas on Female Labor Market Outcomes in Norway." NBER Working Paper .

[6] Bertrand M., Goldin C. and Katz L. F., 2010. "Dynamics of the Gender Gap for Young Professionals in the Financial and Corporate Sectors." American Economic Journal: Applied Economics, 2(3), 228-255.

[7] Bertrand M. and Schoar A., 2003. "Managing With Style: The Effect Of Managers On Firm Policies." The Quarterly Journal of Economics, 118, 1169-1208.

[8] Cardoso A. R. and Winter-Ebmer R., 2007. "Female-Led Firms and Gender Wage Policies." Industrial and Labor Relations Review, 64, 143-163.

[9] Croson, R. and Gneezy, U., 2009. "Gender Differences in Preferences." Journal of Economic Literature, 47(2), 448-474. 
[10] Economist Intelligence Unit, 2010. Women's Economic Opportunity.

[11] Flabbi L., Macis M., Moro A. and Schivardi F., 2013. "Do Female Executives Make a Difference? The Impact of Female Leadership on Firm Performance and Gender Gaps in Wages and Promotions." Mimeo.

[12] Gagliarducci S. and Paserman M. D., 2012. "Gender Interactions within Hierarchies: Evidence from the Political Arena." Review of Economic Studies, 79, 1021-1052.

[13] Goldin, C., Katz, L. F. and Kuziemko, I., 2006 "The Homecoming of American College Women: The Reversal of the Gender Gap in College." Journal of Economic Perspectives, $20(4), 133-156$.

[14] Laible, M-C., 2013. "Gender Diversity in Top Management and Firm Performance: An Analysis with the IAB-Establishment Panel." Mimeo., Institute for Employment Research (IAB).

[15] Matsa D. A. and Miller A., 2013. "A Female Style in Corporate Leadership? Evidence from Quotas." American Economic Journal: Applied Economics, 5, 136-169.

[16] Matsa D. A. and Miller A., 2014. "Workforce Reductions at Women-Owned Businesses in the United States." Industrial and Labor Relations Review, 67(2).

[17] Parrotta P. and Smith, N. , 2013 "Female-Led Firms: Performance and Risk Attitudes." IZA Discussion Paper No. 7613.

[18] Sandberg S., 2013. Lean In: Women, Work, and the Will to Lead, New York: Alfred A. Knopf.

[19] Smith, N., Smith, V. and Verner, M., 2006. "Do Women in Top Management Affect Firm Performance? A Panel Study of 2500 Danish Firms." International Journal of Productivity and Performance Management, 55(7), 569-593. 
[20] Tate, G. and Yang, L., 2014. "Female Leadership and Gender Equity: Evidence from Plant Closure." Journal of Financial Economics, forthcoming.

[21] Wolfers J., 2006. "Diagnosing Discrimination: Stock Returns and CEO Gender." Journal of the European Economic Association, 4, 531-541. 
Table 1: Summary of Exisiting Literature

\begin{tabular}{|c|c|c|c|c|c|}
\hline Study & Sample & $\begin{array}{c}\begin{array}{c}\text { Definition of Female } \\
\text { Leadership }\end{array} \\
\end{array}$ & Outcomes & Methodology & Results \\
\hline \multicolumn{6}{|c|}{ Panel A: The effect of female leadership on corporate performance } \\
\hline \multicolumn{6}{|c|}{ A1: Female CEOs and top executives } \\
\hline Wolfers (2006) & S\&P 1500 companies & Female CEOs & Excess stock returns & OLS, matching & No effect \\
\hline Smith et al. (2006) & Large Danish firms & $\begin{array}{c}\text { Fraction of women among top } \\
\text { executives and in board of } \\
\text { directors }\end{array}$ & $\begin{array}{l}\text { Value added, profits, net } \\
\text { results }\end{array}$ & $\begin{array}{l}\text { Firm fixed effects, IV } \\
\text { (education of male CEO's } \\
\text { spouses) }\end{array}$ & $\begin{array}{l}\text { Positive effect on performance (OLS, } \\
\text { IV); no effect (FE, IV-FE). }\end{array}$ \\
\hline Amore et al. (2013) & Family-controlled firms in Italy & $\begin{array}{c}\text { Fraction female among CEOs } \\
\text { and directors }\end{array}$ & Return on assets & Fixed effects, triple differences & $\begin{array}{l}\text { Positive effect on performance of } \\
\text { female CEOs when coupled with } \\
\text { female directors. }\end{array}$ \\
\hline Parrotta and Smith (2013) & $\begin{array}{l}\text { Danish companies with more } \\
\text { than } 50 \text { employees }\end{array}$ & $\begin{array}{c}\text { Female CEO, female chairman, } \\
\text { and female share among } \\
\text { directors }\end{array}$ & $\begin{array}{l}\text { Investment, profits, returns on } \\
\text { equity, sales (levels and } \\
\text { volatility) }\end{array}$ & Fixed effects & $\begin{array}{c}\text { No effect on levels, female-led firms } \\
\text { have lower variability in all outcome } \\
\text { variables. }\end{array}$ \\
\hline \multicolumn{6}{|c|}{ A2: Women in the board of directors - General } \\
\hline Adams and Ferreira (2009) & $\begin{array}{c}\text { S\&P 500, S\&P MidCaps, S\&P } \\
\text { SmallCap }\end{array}$ & Female directors & $\begin{array}{l}\text { Governance, firm performance } \\
\text { (Tobin's q, return on assets) }\end{array}$ & $\begin{array}{l}\text { Firm fixed effects, IV (fraction } \\
\text { of male directors connected to } \\
\text { female directors) }\end{array}$ & $\begin{array}{l}\text { More attendance, more monitoring, } \\
\text { lower firm performance }\end{array}$ \\
\hline Adams and Funk (2012) & $\begin{array}{l}\text { Publicly traded firms in } \\
\text { Sweden }\end{array}$ & Female CEOs and directors & $\begin{array}{c}\text { Values (achievement, power, } \\
\text { benevolence) and risk } \\
\text { attitudes }\end{array}$ & OLS, fixed effects & $\begin{array}{l}\text { Female directors have higher } \\
\text { benevolence and universalism, less } \\
\text { power oriented, more risk-loving. }\end{array}$ \\
\hline \multicolumn{6}{|c|}{ A3: Women in the board of directors - The Norwegian gender quota experiment } \\
\hline Ahern and Dittmar (2012) & Publicly listed Norwegian firms & Female directors & $\begin{array}{l}\text { Tobin's } Q \text {, excess returns } \\
\text { around announcement of } \\
\text { reform }\end{array}$ & $\begin{array}{c}\text { Event study analysis; } \\
\text { IV(fraction of female directors } \\
\text { in 2002), with firm fixed effects }\end{array}$ & $\begin{array}{c}\text { Stock prices drop at time of } \\
\text { announcement; lower Tobin } Q \text {. }\end{array}$ \\
\hline Matsa and Miller (2013) & $\begin{array}{l}\text { Listed and unlisted firms in } \\
\text { Norway and other Nordic } \\
\text { countries }\end{array}$ & Female directors & $\begin{array}{c}\text { Corporate profits and labor } \\
\text { outcomes }\end{array}$ & $\begin{array}{l}\text { DD (listed and unlisted firms in } \\
\text { Norway, before and after } \\
\text { gender quota); DDD } \\
\text { (comparison to other Nordic } \\
\text { countries) }\end{array}$ & $\begin{array}{l}\text { Fewer workforce reductions, higher } \\
\text { labor costs, lower operating profits. }\end{array}$ \\
\hline
\end{tabular}


Table 1 (contd.): Summary of Exisiting Literature

\begin{tabular}{|c|c|c|c|c|c|}
\hline Study & Sample & $\begin{array}{l}\text { Definition of Female } \\
\text { Leadership }\end{array}$ & Outcomes & Methodology & Results \\
\hline \multicolumn{6}{|c|}{ Panel B: The effect of female leadership on employee outcomes } \\
\hline Flabbi et al. (2013) & Italian manufacturing firms & $\begin{array}{l}\text { Female executives and female } \\
\text { CEO }\end{array}$ & $\begin{array}{l}\text { Sales, value added and TFP per } \\
\text { worker; wages. }\end{array}$ & Fixed effects & $\begin{array}{l}\text { Positive interaction effect of female } \\
\text { leadership and female workers on } \\
\text { firm performance; female leaderhsip } \\
\text { raises female wages at the top, } \\
\text { lowers wages at the bottom. }\end{array}$ \\
\hline $\begin{array}{c}\text { Cardoso and Winter-Ebmer } \\
\text { (2007) }\end{array}$ & $\begin{array}{l}\text { Private Portuguese firms in } \\
\text { manufacturing and services }\end{array}$ & $\begin{array}{l}\text { Female owners or female top- } \\
\text { paid managers }\end{array}$ & Wages & OLS, fixed effects & $\begin{array}{l}\text { Higher female wages and lower male } \\
\text { wages in female-led firms. }\end{array}$ \\
\hline Tate and Yang (2014) & $\begin{array}{c}\text { Non-farm establishments in } 23 \\
\text { US states }\end{array}$ & $\begin{array}{c}\text { Fraction female among top } 5 \\
\text { paid workers }\end{array}$ & $\begin{array}{l}\text { Wage loss following plant } \\
\text { closure }\end{array}$ & $\begin{array}{l}\text { Diff in Diff (comparison of } \\
\text { workers who move from same } \\
\text { closing plant to same hiring } \\
\text { plant). }\end{array}$ & $\begin{array}{l}\text { Women experience smaller relative } \\
\text { wage loss after displacement if hired } \\
\text { by female-led firms. }\end{array}$ \\
\hline Bertrand et al. (2014) & $\begin{array}{l}\text { Public limited liability (ASA) } \\
\text { companies in Norway }\end{array}$ & Female directors & $\begin{array}{l}\text { Representation of women at } \\
\text { various percentiles of the wage } \\
\text { distribution; gender wage gap. }\end{array}$ & $\begin{array}{l}\text { IV(fraction of female directors } \\
\text { in 2002), with firm fixed effects }\end{array}$ & $\begin{array}{l}\text { Increased representation of women } \\
\text { among top } 5 \text { highest earners; no } \\
\text { effect at other points in the } \\
\text { distrbution; no effect on the gender } \\
\text { wage gap }\end{array}$ \\
\hline Matsa and Miller (2014) & Privately owned US firms & $\begin{array}{l}\text { Majority female in ownership } \\
\text { and control }\end{array}$ & $\begin{array}{c}\text { Workforce reductions during } \\
\text { Great Recession }\end{array}$ & $\begin{array}{l}\text { OLS with extensive set of } \\
\text { controls, matching. }\end{array}$ & $\begin{array}{l}\text { Female owned firms had smaller } \\
\text { workforce reductions. }\end{array}$ \\
\hline
\end{tabular}


Table 2: Sample Description and Fraction of Women in Management

\begin{tabular}{ccccc}
\hline \hline & \multicolumn{5}{c}{ Number of } \\
Year & $\begin{array}{c}\text { Number of } \\
\text { establishments }\end{array}$ & $\begin{array}{c}\text { Fraction women } \\
\text { establishments in } \\
\text { the analysis }\end{array}$ & $\begin{array}{c}\text { Fraction women } \\
\text { management }\end{array}$ & $\begin{array}{c}\text { among working } \\
\text { proprietors }\end{array}$ \\
\hline 1993 & 4,265 & 3,346 & - & 0.156 \\
1994 & 4,154 & 3,168 & - & - \\
1995 & 4,134 & 3,063 & - & - \\
1996 & 4,949 & 3,363 & - & - \\
1997 & 4,591 & 2,935 & - & 0.080 \\
1998 & 5,364 & 3,202 & - & 0.092 \\
1999 & 5,749 & 3,354 & - & 0.107 \\
2000 & 9,776 & 6,069 & - & 0.099 \\
2001 & 11,522 & 7,084 & - & 0.1164 \\
2002 & 11,988 & 7,079 & - & 0.116 \\
2003 & 12,233 & 6,625 & - & 0.116 \\
2004 & 12,533 & 6,770 & 0.139 & 0.117 \\
2005 & 12,904 & 6,768 & - & 0.122 \\
2006 & 12,867 & 6,483 & - & 0.122 \\
2007 & 12,366 & 6,360 & - & 0.130 \\
2008 & 12,427 & 6,206 & 0.151 & 0.140 \\
2009 & 12,900 & 6,295 & - & 0.140 \\
2010 & 13,304 & 5,883 & - & 0.151 \\
2011 & 13,317 & 5,886 & - & 0.158 \\
2012 & 13,707 & 6,204 & 0.185 & 0.123 \\
Total & 195,050 & 106,143 & 0.158 & \\
\hline
\end{tabular}

Notes: Author's calculations based on the IAB Establishment Panel and Linked EmployerEmployee data. Proprietors also include family members of the proprietors. The top management includes executives, proprietors, directors, branch managers and works managers. 
Table 3: Summary Statistics of Establishments

\begin{tabular}{|c|c|c|c|c|c|}
\hline & $\mathrm{N}$ & Frequency & & $\mathrm{N}$ & Frequency \\
\hline Size: & & & Type: & & \\
\hline $10-19$ & 13,636 & 0.129 & Single & 54,191 & 0.566 \\
\hline $20-49$ & 25,616 & 0.241 & Branch & 26,899 & 0.281 \\
\hline $50-99$ & 16,861 & 0.159 & Head Office & 14,675 & 0.153 \\
\hline 100-199 & 14,673 & 0.138 & & & \\
\hline 200-499 & 17,240 & 0.162 & Collective wage agreement: & & \\
\hline $500-999$ & 8,251 & 0.078 & Industry-wide & 58,846 & 0.617 \\
\hline 1000-4999 & 8,915 & 0.084 & Company & 7,317 & 0.010 \\
\hline $5000+$ & 951 & 0.009 & No agreement & 7,317 & 0.283 \\
\hline Sector: & & & Region: & & \\
\hline Agriculture & 937 & 0.009 & Schleswig-Holstein & 6,938 & 0.065 \\
\hline Mining & 2,310 & 0.022 & Hamburg & 4,016 & 0.038 \\
\hline Manufacturing & 30,140 & 0.284 & Niedersachsen & 11,643 & 0.110 \\
\hline Construction & 6,623 & 0.062 & Bremen & 6,701 & 0.063 \\
\hline Retail & 12,729 & 0.120 & Nordrhein-Westfalen & 18,559 & 0.175 \\
\hline Transport & 5,434 & 0.051 & Hessen & 9,978 & 0.094 \\
\hline Finance & 4,498 & 0.042 & Rheinland-Pfalz/Saarland & 7,480 & 0.071 \\
\hline Education & 3,977 & 0.038 & Baden-W,rttemberg & 13,359 & 0.126 \\
\hline Health & 9,786 & 0.092 & Bayern & 13,388 & 0.126 \\
\hline Public & 12,220 & 0.115 & Saarland & 5,699 & 0.054 \\
\hline Other & 8,624 & 0.081 & Berlin & 8,382 & 0.079 \\
\hline Legal form: & & & Observations: & & \\
\hline Individually-owned & 6,563 & 0.068 & 1 & 7,559 & 0.299 \\
\hline Partnership & 5,809 & 0.060 & 2 & 4,125 & 0.163 \\
\hline Limited liability company & 53,534 & 0.554 & 3 & 2,481 & 0.098 \\
\hline Company limited by shares & 6,999 & 0.072 & $4+$ & 11,151 & 0.440 \\
\hline Public corporation & 16,454 & 0.170 & & & \\
\hline Other & 7,317 & 0.076 & & & \\
\hline
\end{tabular}

Notes: $N$ is the $\mathrm{n}$. of establishments in the panel. All variables are $0 / 1$ dummies, and the frequency represents the fraction of each category in the sample. Size represents total employment as reported in the Establishment Survey, inclusive of workers not subject to Social Security. Branch also includes middle-level authorities. 
Table 4: Summary Statistics of Dependent Variables

\begin{tabular}{|c|c|c|c|c|c|c|}
\hline \multicolumn{7}{|l|}{ Panel A: Firm outcomes } \\
\hline & $\mathrm{N}$ & Mean & $\exp ($ Mean) & Std. Dev. & Min & Max \\
\hline Log (business volume per worker) & 55,425 & 11.733 & $124,661.8$ & 1.137 & -4.635 & 19.067 \\
\hline Log (investments per worker) & 65,029 & 5.337 & 207.9 & 5.152 & -8.825 & 15.578 \\
\hline Log (wage bill per worker) & 90,857 & 7.642 & $2,083.0$ & 0.474 & 4.017 & 10.192 \\
\hline Log (employment) & 106,143 & 4.670 & 106.7 & 1.507 & 2.303 & 11.167 \\
\hline Hiring rate & 78,229 & 0.052 & - & 0.128 & 0 & 1 \\
\hline Termination rate & 78,303 & 0.049 & - & 0.107 & 0 & 1 \\
\hline Pct. workers on flexible time & 53,424 & 0.507 & - & 0.455 & 0 & 1 \\
\hline Female friendly policy index & 26,094 & 0.146 & - & 0.204 & 0 & 1 \\
\hline Any workplace childcare facilities & 26,067 & 0.086 & - & 0.281 & 0 & 1 \\
\hline Any help for employees on parental leave & 26,051 & 0.262 & - & 0.440 & 0 & 1 \\
\hline Any promotion of female junior staff & 26,045 & 0.096 & - & 0.294 & 0 & 1 \\
\hline \multicolumn{7}{|l|}{ Panel B: Employee Outcomes (bottom 95\%) } \\
\hline & $\mathrm{N}$ & Mean & $\exp ($ Mean) & Std. Dev. & Min & Max \\
\hline Log female full-time employment & 87,252 & 2.875 & 17.7 & 1.741 & 0 & 9.039 \\
\hline Log male full-time employment & 87,252 & 3.567 & 35.4 & 1.837 & 0 & 10.727 \\
\hline Log female part-time employment & 87,252 & 2.225 & 9.3 & 1.747 & 0 & 8.688 \\
\hline Log male part-time employment & 87,252 & 1.102 & 3.0 & 1.348 & 0 & 8.219 \\
\hline Log female full-time wage & 75,107 & 4.182 & 65.5 & 0.412 & -1.282 & 5.153 \\
\hline Log male full-time wage & 75,616 & 4.352 & 77.7 & 0.401 & -0.692 & 5.153 \\
\hline Log female part-time wage & 55,666 & 3.377 & 29.3 & 1.016 & -2.659 & 5.153 \\
\hline Log male part-time wage & 70,295 & 3.531 & 34.2 & 0.709 & -1.965 & 5.135 \\
\hline
\end{tabular}

Notes: Business volume is either sales or assets in the calendar year prior to the survey. Wage bill is the monthly wage bill in June. Business volume and Investments are measured for private sector firms only. Female friendly policy index is the average of seven female friendly policies: provision of childcare, parental leave, promotion and mentoring of female junior staff, support for employees with relatives requiring care, consideration of needs of employees with care responsibilities, member of a network of family friendly companies (all 0/1 dummies), and other (unspecified). In Panel B, outcomes refer to bottom 95\% wage workers: employment is the number of workers, and wages are per day. All monetary values measured in 2005 euros. 
Table 5: Fraction of Women in Top Management and Establishment Outcomes

\section{PANEL A}

\begin{tabular}{|c|c|c|c|c|c|c|c|c|c|c|c|c|}
\hline & \multicolumn{4}{|c|}{ Log (business volume per worker) } & \multicolumn{4}{|c|}{ Log (investments per worker) } & \multicolumn{4}{|c|}{ Log (wage bill per worker) } \\
\hline & OLS & & $\mathrm{FE}$ & $\mathrm{FE}+\mathrm{t}$ & OLS & & FE & $\mathrm{FE}+\mathrm{t}$ & OLS & & $\mathrm{FE}$ & $\mathrm{FE}+\mathrm{t}$ \\
\hline \multirow{3}{*}{$\begin{array}{l}\text { Fraction women in top } \\
\text { layer of management }\end{array}$} & -0.368 & $* * *$ & 0.001 & - & -1.353 & $* * *$ & -0.311 & - & -0.188 & $* * *$ & 0.012 & 0.059 \\
\hline & $(0.038)$ & & $(0.113)$ & - & $(0.222)$ & & $(1.212)$ & - & $(0.015)$ & & $(0.031)$ & $(0.065)$ \\
\hline & $\{7,009\}$ & & $\{7,009\}$ & - & $\{8,294\}$ & & $\{8,294\}$ & - & $\{15,445\}$ & & $\{15,445\}$ & $\{4,140\}$ \\
\hline \multirow{3}{*}{$\begin{array}{l}\text { Fraction women among } \\
\text { working proprietors }\end{array}$} & -0.249 & $* * *$ & 0.001 & -0.006 & -0.742 & $* * *$ & -0.030 & -0.033 & -0.149 & $* * *$ & -0.012 & -0.013 \\
\hline & $(0.028)$ & & $(0.015)$ & $(0.015)$ & $(0.136)$ & & (0.193) & $(0.236)$ & $(0.012)$ & & $(0.010)$ & $(0.011)$ \\
\hline & $\{35,208\}$ & & $\{35,208\}$ & $\{28,336\}$ & $\{40,375\}$ & & $\{40,375\}$ & $\{32,913\}$ & $\{54,916\}$ & & $\{54,916\}$ & $\{42,696\}$ \\
\hline
\end{tabular}

\section{PANEL B}

Fraction women in top layer of management

\begin{tabular}{|c|c|c|c|}
\hline \multicolumn{4}{|c|}{ Log (employment) } \\
\hline OLS & & $\mathrm{FE}$ & $\mathrm{FE}+\mathrm{t}$ \\
\hline-0.378 & $* * *$ & 0.012 & 0.015 \\
\hline$(0.033)$ & & $(0.032)$ & $(0.042)$ \\
\hline$\{18,410\}$ & & $\{18,410\}$ & $\{5,325\}$ \\
\hline-0.272 & $* * *$ & 0.000 & 0.010 \\
\hline$(0.029)$ & & $(0.010)$ & $(0.008)$ \\
\hline$\{61,865\}$ & & $\{61,865\}$ & $\{48,381\}$ \\
\hline
\end{tabular}

\begin{tabular}{|c|c|c|c|c|c|c|c|}
\hline \multicolumn{4}{|c|}{ Hiring Rate } & \multicolumn{4}{|c|}{ Termination Rate } \\
\hline OLS & & $\mathrm{FE}$ & $\mathrm{FE}+\mathrm{t}$ & OLS & & $\mathrm{FE}$ & $\mathrm{FE}+\mathrm{t}$ \\
\hline 0.021 & $* * *$ & 0.000 & -0.004 & 0.017 & $* * *$ & 0.005 & -0.004 \\
\hline$(0.005)$ & & $(0.015)$ & $(0.020)$ & $(0.004)$ & & (0.010) & $(0.015)$ \\
\hline$\{14,295\}$ & & $\{14,295\}$ & $\{4,272\}$ & $\{14,306\}$ & & $\{14,306\}$ & $\{4,290\}$ \\
\hline 0.025 & $* * *$ & 0.004 & -0.006 & 0.017 & $* * *$ & -0.001 & -0.004 \\
\hline$(0.004)$ & & $(0.004)$ & $(0.005)$ & $(0.004)$ & & $(0.003)$ & $(0.004)$ \\
\hline$\{46,147\}$ & & $\{46,147\}$ & $\{38,109\}$ & $\{46,203\}$ & & $\{46,203\}$ & $\{38,165\}$ \\
\hline
\end{tabular}

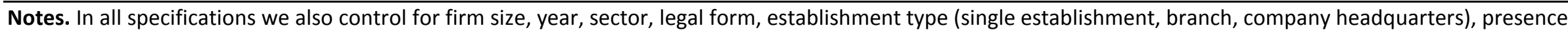

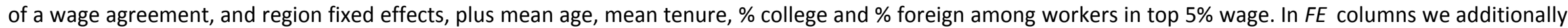

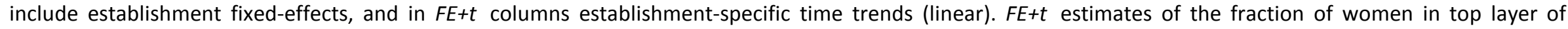

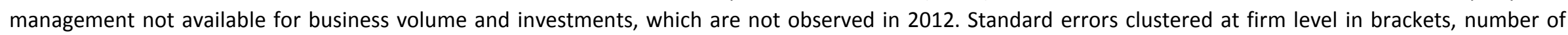
observations in curly brackets. See also footnotes to Tables 2-4. 
Table 6: Fraction of Women in Top Management and Female Friendly Policies

PANEL A

Pct. workers on flexible time Female friendly policy index

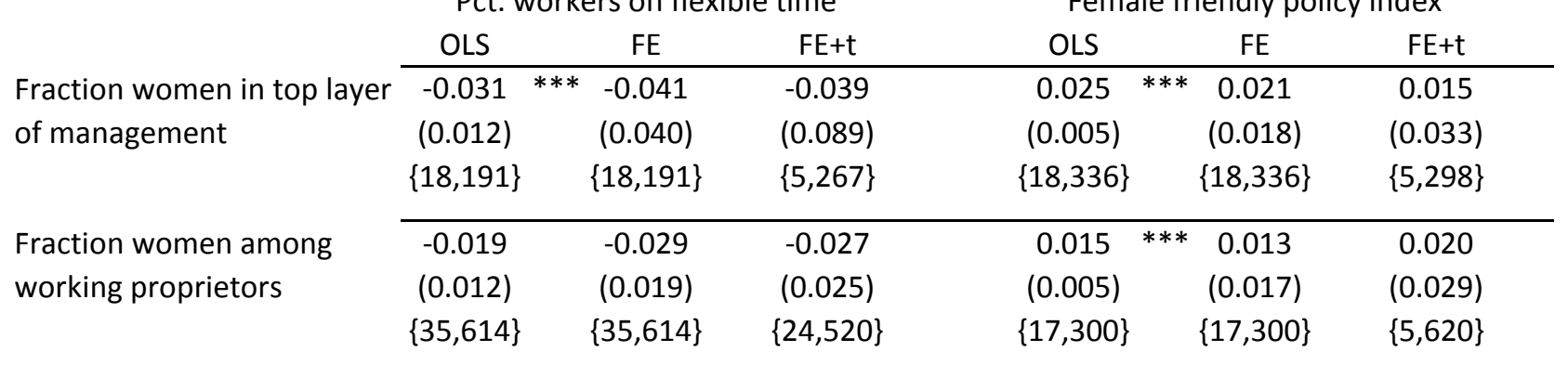

PANEL B

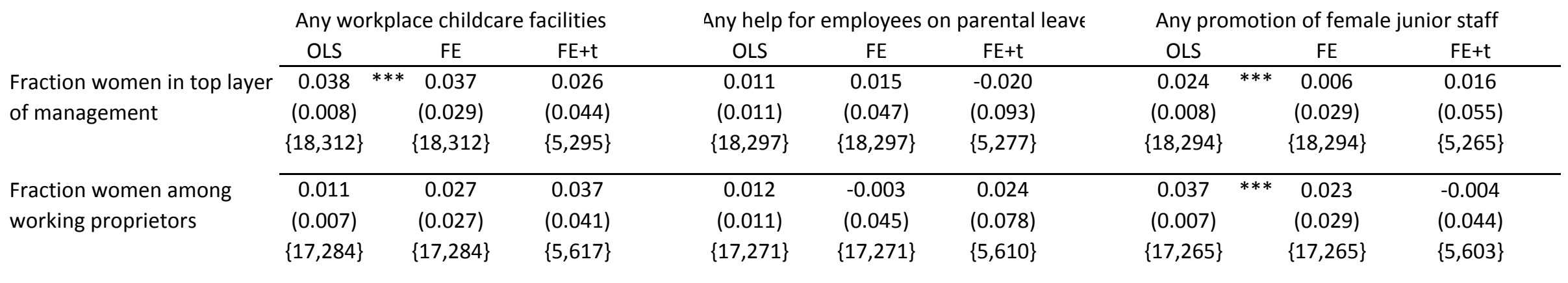

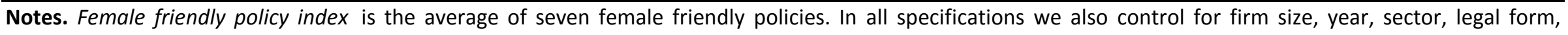

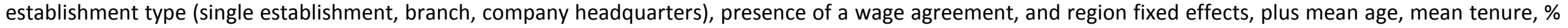

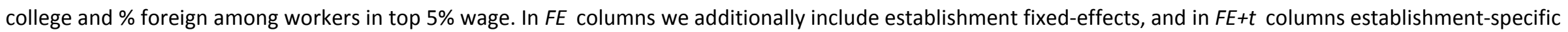
time trends (linear). Standard errors clustered at firm level in brackets, number of observations in curly brackets. See also footnotes to Tables 2-4. 
PANEL A

\begin{tabular}{|c|c|c|c|c|c|c|c|c|}
\hline & \multicolumn{4}{|c|}{ Log (female full-time employment) } & \multicolumn{4}{|c|}{ Log (male full-time employment) } \\
\hline & OLS & & $\mathrm{FE}$ & $\mathrm{FE}+\mathrm{t}$ & OLS & & $\mathrm{FE}$ & $\mathrm{FE}+\mathrm{t}$ \\
\hline \multirow{3}{*}{$\begin{array}{l}\text { Fraction women in top } \\
\text { layer of management }\end{array}$} & -0.140 & $* * *$ & 0.059 & - & -0.858 & $* * *$ & 0.007 & - \\
\hline & $(0.050)$ & & $(0.080)$ & - & $(0.053)$ & & $(0.082)$ & - \\
\hline & $\{11,448\}$ & & $\{11,456\}$ & - & $\{11,448\}$ & & $\{11,456\}$ & - \\
\hline \multirow{3}{*}{$\begin{array}{l}\text { Fraction women among } \\
\text { working proprietors }\end{array}$} & -0.132 & $* * *$ & -0.001 & -0.002 & -0.574 & $* * *$ & -0.012 & -0.004 \\
\hline & $(0.040)$ & & $(0.017)$ & $(0.016)$ & $(0.041)$ & & $(0.016)$ & $(0.014)$ \\
\hline & $\{49,088\}$ & & $\{49,127\}$ & $\{37,430\}$ & $\{49,088\}$ & & $\{49,127\}$ & $\{37,430\}$ \\
\hline
\end{tabular}

\section{PANEL B}

Fraction women in top layer of management

Fraction women among working proprietors Log (female part-time employment)

Log (male part-time employment)

\begin{tabular}{|c|c|c|c|c|c|c|}
\hline OLS & $\mathrm{FE}$ & $\mathrm{FE}+\mathrm{t}$ & OLS & & $\mathrm{FE}$ & $\mathrm{FE}+\mathrm{t}$ \\
\hline 0.096 & 0.054 & - & -0.275 & $* * *$ & 0.016 & - \\
\hline$(0.050)$ & (0.094) & - & $(0.045)$ & & (0.110) & - \\
\hline$\{11,448\}$ & $\{11,456\}$ & - & $\{11,448\}$ & & $\{11,456\}$ & - \\
\hline-0.002 & -0.001 & 0.021 & -0.150 & $* * *$ & 0.001 & 0.028 \\
\hline$(0.041)$ & $(0.021)$ & $(0.019)$ & $(0.035)$ & & $(0.024)$ & $(0.026)$ \\
\hline$\{49,088\}$ & $\{49,127\}$ & $\{37,430\}$ & $\{49,088\}$ & & $\{49,127\}$ & $\{37,430\}$ \\
\hline
\end{tabular}

Notes. All outcomes measured at time $t$, in 2005 euros (where applicable), and refer to the bottom 95\% wage workers. Wages are per day. In all specifications we also control for firm size, year, sector, legal form, establishment type (single establishment, branch, company headquarters), presence of a wage agreement, and region fixed effects, plus mean age, mean tenure, \% college and \% foreign among workers in top 5\% wage. In $F E$ columns we additionally include establishment fixed-effects, and in $F E+t$ columns establishment-specific time trends (linear). $F E+t$ estimates of the fraction of women in top layer of management not available for employee-level outcomes, which are not observed in 2012. Standard errors clustered at firm level in brackets, number of observations in curly brackets. See also footnotes 
PANEL A

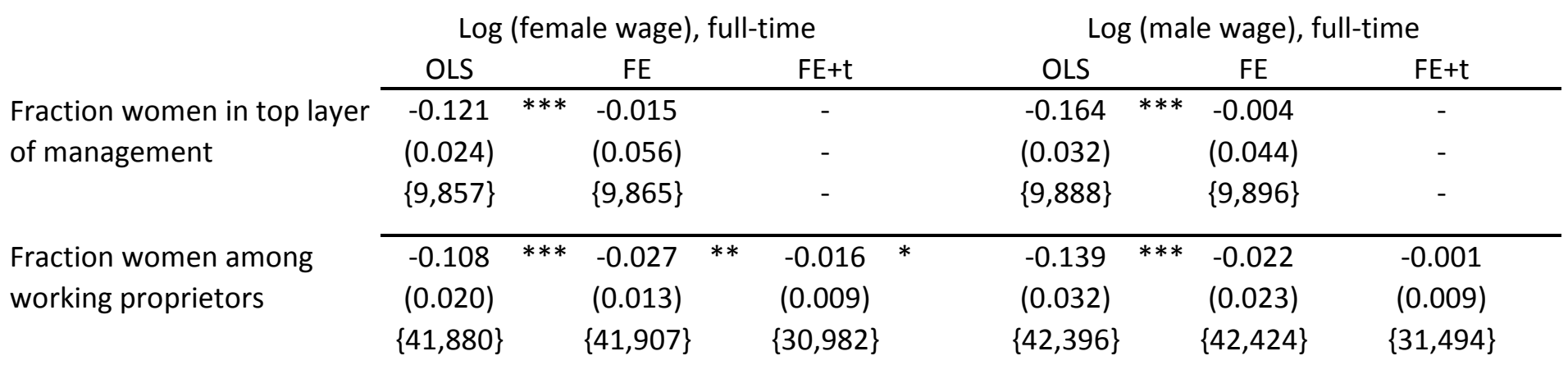

PANEL B

\begin{tabular}{|c|c|c|c|c|c|c|c|c|}
\hline & \multicolumn{4}{|c|}{ Log (female wage), part-time } & \multicolumn{4}{|c|}{ Log (male wage), part-time } \\
\hline & OLS & & $\mathrm{FE}$ & $\mathrm{FE}+\mathrm{t}$ & OLS & & FE & $\mathrm{FE}+\mathrm{t}$ \\
\hline \multirow{3}{*}{$\begin{array}{l}\text { Fraction women in top layer } \\
\text { of management }\end{array}$} & -0.077 & $* *$ & 0.044 & - & -0.125 & $* * *$ & 0.092 & - \\
\hline & $(0.037)$ & & (0.099) & - & $(0.051)$ & & $(0.181)$ & - \\
\hline & $\{9,486\}$ & & $\{9,492\}$ & - & $\{8,162\}$ & & $\{8,168\}$ & - \\
\hline \multirow{3}{*}{$\begin{array}{l}\text { Fraction women among } \\
\text { working proprietors }\end{array}$} & -0.074 & $* * *$ & -0.012 & -0.004 & -0.075 & * & -0.044 & -0.035 \\
\hline & $(0.027)$ & & (0.013) & $(0.012)$ & $(0.042)$ & & (0.032) & $(0.037)$ \\
\hline & $\{39,279\}$ & & $\{39,298\}$ & $\{28,909\}$ & $\{32,046\}$ & & $\{32,063\}$ & $\{23,034\}$ \\
\hline
\end{tabular}

Notes. All outcomes measured at time $t$, in 2005 euros (where applicable), and refer to the bottom 95\% of wage workers. Wages are per day. In all specifications we also control for firm size, year, sector, legal form, establishment type (single establishment, branch, company headquarters), presence of a wage agreement, and region fixed effects, plus mean age, mean tenure, \% college and \% foreign among workers in top $5 \%$ wage. In $F E$ columns we additionally include establishment fixed-effects, and in $F E+t$ columns establishment-specific time trends (linear). $F E+t$ estimates of the fraction of women in top layer of management not available for employee-level outcomes, which are not observed in 2012. Standard errors clustered at firm level in brackets, number of observations in curly brackets. See also footnotes to 
Table 9: Fraction of Women Among Working Proprietors and Establishment Outcomes, by Establishment Size

\begin{tabular}{|c|c|c|c|c|c|c|c|c|c|}
\hline \multirow{3}{*}{ PANEL A } & \multicolumn{3}{|c|}{$10-49$} & \multicolumn{3}{|c|}{$50-499$} & \multicolumn{3}{|c|}{$500+$} \\
\hline & \multicolumn{3}{|c|}{ Log (business volume per worker) } & \multicolumn{3}{|c|}{ Log (business volume per worker) } & \multicolumn{3}{|c|}{ Log (business volume per worker) } \\
\hline & OLS & $\mathrm{FE}$ & $\mathrm{FE}+\mathrm{t}$ & OLS & $\mathrm{FE}$ & $\mathrm{FE}+\mathrm{t}$ & OLS & $\mathrm{FE}$ & $\mathrm{FE}+\mathrm{t}$ \\
\hline \multirow{3}{*}{$\begin{array}{l}\text { Fraction women among } \\
\text { working proprietors }\end{array}$} & -0.043 & -0.012 & 0.007 & 0.038 & 0.037 & -0.066 & 0.095 & 0.078 & 0.085 \\
\hline & $(0.039)$ & (0.059) & $(0.070)$ & $(0.050)$ & $(0.070)$ & $(0.082)$ & $(0.118)$ & $(0.128)$ & (0.179) \\
\hline & $\{17,472\}$ & $\{17,472\}$ & $\{14,051\}$ & $\{16,755\}$ & $\{16,755\}$ & $\{13,595\}$ & $\{4,705\}$ & $\{4,705\}$ & $\{3,825\}$ \\
\hline \multicolumn{10}{|l|}{ PANEL B } \\
\hline & \multicolumn{3}{|c|}{ Female friendly policy index } & \multicolumn{3}{|c|}{ Female friendly policy index } & \multicolumn{3}{|c|}{ Female friendly policy index } \\
\hline \multirow{4}{*}{$\begin{array}{l}\text { Fraction women among } \\
\text { working proprietors }\end{array}$} & OLS & $\mathrm{FE}$ & $\mathrm{FE}+\mathrm{t}$ & OLS & $\mathrm{FE}$ & $\mathrm{FE}+\mathrm{t}$ & OLS & $\mathrm{FE}$ & $\mathrm{FE}+\mathrm{t}$ \\
\hline & 0.012 & 0.018 & 0.043 & 0.019 & 0.011 & -0.002 & 0.006 & -0.034 & -0.092 \\
\hline & $(0.006)$ & $(0.020)$ & $(0.029)$ & $(0.008)$ & $(0.031)$ & $(0.054)$ & $(0.031)$ & $(0.112)$ & $(0.212)$ \\
\hline & $\{7,493\}$ & $\{7,493\}$ & $\{2,477\}$ & $\{7,834\}$ & $\{7,834\}$ & $\{2,515\}$ & $\{1,973\}$ & $\{1,973\}$ & $\{628\}$ \\
\hline
\end{tabular}

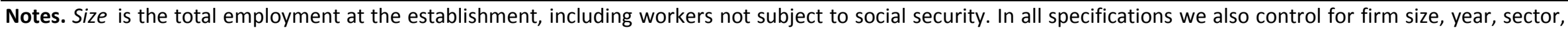

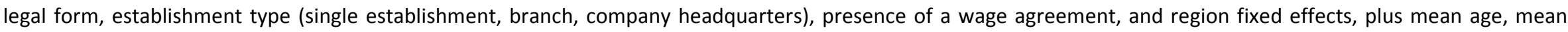

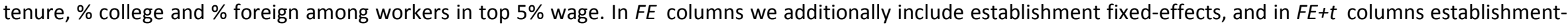
specific time trends (linear). Standard errors clustered at firm level in brackets, number of observations in curly brackets. See also footnote to Tables $2-4$. 
Table 10: Fraction of Women Among Working Proprietors and Employee Outcomes, by Establishment Size

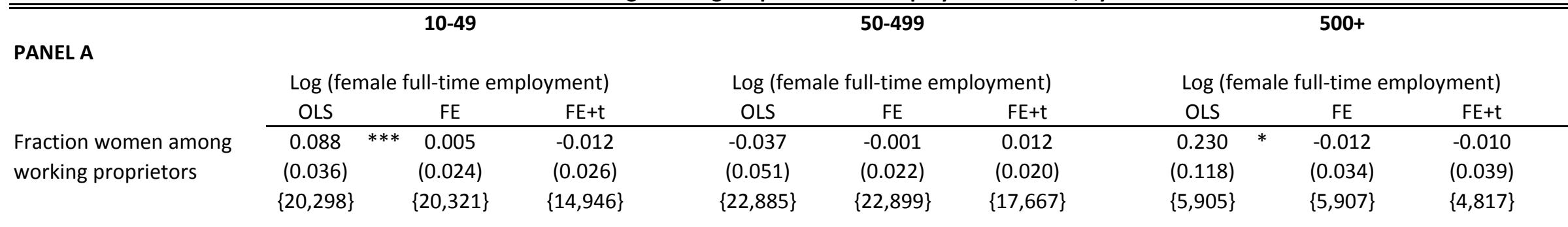

\section{PANEL B}

Fraction women among working proprietors

\begin{tabular}{|c|c|c|c|c|c|c|c|c|c|}
\hline \multicolumn{3}{|c|}{ Log (male full-time employment) } & \multicolumn{3}{|c|}{ Log (male full-time employment) } & \multicolumn{4}{|c|}{ Log (male full-time employment) } \\
\hline OLS & $\mathrm{FE}$ & $\mathrm{FE}+\mathrm{t}$ & OLS & $\mathrm{FE}$ & $\mathrm{FE}+\mathrm{t}$ & OLS & & $\mathrm{FE}$ & $\mathrm{FE}+\mathrm{t}$ \\
\hline-0.349 & -0.008 & 0.001 & -0.496 & -0.004 & 0.004 & -0.337 & $* * *$ & -0.050 & -0.072 \\
\hline$(0.038)$ & $(0.021)$ & $(0.023)$ & $(0.058)$ & $(0.022)$ & (0.019) & (0.139) & & $(0.047)$ & $(0.054)$ \\
\hline$\{20,298\}$ & $\{20,321\}$ & $\{14,946\}$ & $\{22,885\}$ & $\{22,899\}$ & $\{17,667\}$ & $\{5,905\}$ & & $\{5,907\}$ & $\{4,817\}$ \\
\hline
\end{tabular}

\section{PANEL C}

Fraction women among working proprietors

\begin{tabular}{|c|c|c|c|c|c|c|c|c|c|c|c|c|c|}
\hline \multicolumn{4}{|c|}{ Log (female wage), full-time } & \multicolumn{4}{|c|}{ Log (female wage), full-time } & \multicolumn{6}{|c|}{ Log (female wage), full-time } \\
\hline OLS & & $\mathrm{FE}$ & $\mathrm{FE}+\mathrm{t}$ & OLS & & $\mathrm{FE}$ & $\mathrm{FE}+\mathrm{t}$ & OLS & & FE & & $\mathrm{FE}+\mathrm{t}$ & \\
\hline-0.081 & $* * *$ & 0.009 & 0.016 & -0.084 & $* * *$ & -0.006 & -0.007 & -0.133 & $* * *$ & -0.044 & $* *$ & -0.024 & $*$ \\
\hline$(0.017)$ & & $(0.016)$ & $(0.019)$ & $(0.018)$ & & $(0.007)$ & $(0.008)$ & $(0.036)$ & & $(0.020)$ & & $(0.013)$ & \\
\hline$\{15,905\}$ & & $\{15,917\}$ & $\{11,172\}$ & $\{20,157\}$ & & $\{20,170\}$ & $\{15,081\}$ & $\{5,818\}$ & & $\{5,820\}$ & & $\{4,729\}$ & \\
\hline
\end{tabular}

\section{PANEL D}

Fraction women among working proprietors

\begin{tabular}{|c|c|c|c|c|c|c|c|c|c|c|c|}
\hline \multicolumn{4}{|c|}{ Log (male wage), full-time } & \multicolumn{4}{|c|}{ Log (male wage), full-time } & \multicolumn{4}{|c|}{ Log (male wage), full-time } \\
\hline OLS & & $\mathrm{FE}$ & $\mathrm{FE}+\mathrm{t}$ & OLS & & $\mathrm{FE}$ & $\mathrm{FE}+\mathrm{t}$ & OLS & & FE & $\mathrm{FE}+\mathrm{t}$ \\
\hline-0.117 & $* * *$ & 0.010 & -0.011 & -0.104 & $* * *$ & 0.001 & 0.007 & -0.176 & $* * *$ & -0.040 & -0.004 \\
\hline$(0.018)$ & & $(0.013)$ & $(0.014)$ & $(0.020)$ & & $(0.011)$ & $(0.012)$ & $(0.060)$ & & $(0.036)$ & $(0.013)$ \\
\hline$\{16,386\}$ & & $\{16,399\}$ & $\{11,662\}$ & $\{20,196\}$ & & $\{20,209\}$ & $\{15,108\}$ & $\{5,814\}$ & & $\{5,816\}$ & $\{4,724\}$ \\
\hline
\end{tabular}

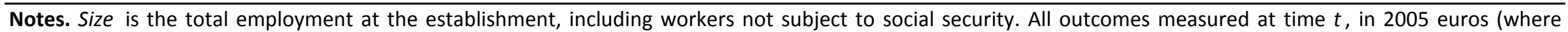

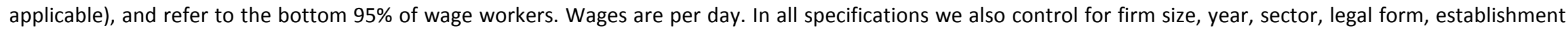

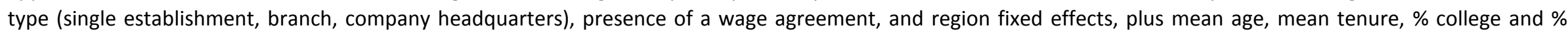

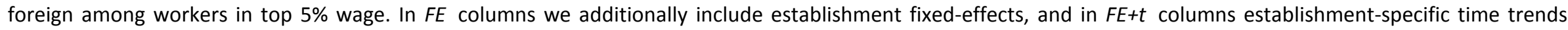
(linear). Standard errors clustered at firm level in brackets, number of observations in curly brackets. See also footnote to Tables $2-4$. 